\title{
Obstacles and Solutions to Chinese International Trade Under "The Belt and Road" Policy
}

\author{
Huagang Li \\ Panyapiwat Institute of Management \\ Bangkok,Thailand \\ gzlihg@163.com
}

Ersi Liu*

Yunnan University of Finance and Economic Kunming,China

Liuersi309@126.com

Jing Zeng

Guangzhou College of South China University of Technology

Guangzhou, China

zengjing39@163.com

\begin{abstract}
Under "The Belt and Road" policy, China largely rely on the existing bilateral and multilateral relationships with other countries through the fields of transportation, communication, trade, investment, bilateral and multilateral economic activities in order to achieve the expansion of trade and cultural communication purposes. This article will discuss some barriers and solutions to Chinese international trade under "The Belt and Road" policy.
\end{abstract}

Keywords- "The Belt and Road"; regional trade; challenges and opportunities; barriers and solutions

\section{INTRODUCTION}

Entire region. The public are quite optimistic about the future prospect of the idea since it complies with the trend of regional development. However, the fact is that in the implementation process, how to help the countries that are located in the middle of Eurasia stimulate economic growth for a long time is both an opportunity and challenge for China.

\section{Positive IMPACTS OF “THE BELT AND ROAD”}

\section{A. Enhance cooperations among countries}

"Silk Road Economic Belt" will strengthen trade cooperation among countries along the road to create a favorable opportunity. The top-level design and overall planning of "The Belt and Road" strategy will be conducive to the improvement of the diplomatic relationship. Based on the research of Gao Jialin (2015) [2], it is conducive to promoting trade and investment facilitation, promoting the formation of a unified market, establishing the two integrated final product market, the expansion of final product trade, optimizing trade structure, realizing the complementary advantages, the interconnection and interoperability of economy and trade and finally promoting the coordinated development of regional economy. It will be developed into the third largest trading center in the world, following the axis of the Atlantic and the Pacific trade.

\footnotetext{
* Corresponding author
}

\section{B. Promote coordinated development in the domestic}

"The Belt and Road" will drive the openness of the northwest and southwest regions and increase international trade, stimulate economic boom in the southwest and northwest areas, and balance the regional pattern of foreign trade. Narrow the developmental gap among domestic regions, achieve regional integration strategy, and promote the economic development of the whole society.

It will also strengthen the complementation among different industries and consolidate the foundation of regional cooperation. Chinese rapid economic development has led to the rising demand for energy resources, such as crude oil and liquefied petroleum gas. On the other hand, the level of Chinese tertiary industry and manufacturing competency has increased significantly. China has more connections with various regions and countries along "The Belt and Road", which lays the foundation for the depth economic development in the future.

\section{BARRIERS OF "THE BELT AND ROAD"}

\section{A. The concerns from neighboring countries}

The original intention of "The Belt and Road" is to strengthen the regional economy and to promote the relationship in the region. However, in reality, most countries are cautious in openness to China. On one hand, they intend to obtain more capital, technology, market and financial aid from China. On the other hand, they are worried about overdependence on Chinese economy due to the further openness to China. He Maochun (2015) et al [3] argues that ASEAN, Central Asia and Africa have different concerns and issues. How to improve the cooperation, expand cooperative areas, enhance trade and investment facilitation, other aspects of the overall coordination and avoid the "China Threat Theory", are all main issues in China.

\section{B. The competition among significant countries}

It is clear that "The Belt and Road" goes through the region that is the main areas of the production of the world's natural resources so that it has great strategic significance. Russia, 
America, the European Union and Japan all have their own ideas in terms of development. Based on the research result of Sun Li (2012) [4], American "the New Silk Road Strategy" and Japanese "New Silk Road diplomacy" are to compete with China. Even Russia and India regard as the Central Asian and India Ocean areas as their traditional scope of influence respectively. Both countries have doubts and resistance about any foreign countries. This is the reason why the international media kept silent or had unfriendly attitude towards "The Belt and Road" idea when China proposed it.

\section{The opposite attitude within Chinese territory}

Compared with the reaction in the world, "The Belt and Road" in China is quite popular. According to unofficial statistics, there were at least 30 cities that declared themselves as the starting point of "The Belt and Road". Sun Yi (2015) [5] indicates that "Free trade area" and "integration" have appeared in various regions, and these cities hope that they can obtain the most resources in the shortest time. It must be faced with a problem of the coordination. Unfortunately, national supervision has not started, coordinative and cooperative institutions cross regions or departments have not established and coordination mechanism is not yet clear. In order to implement "The Belt and Road" plan, what needs to solve first is how to balance the interests of various provinces and cities in the region. Therefore, in practice, either the speed of the implementation or the difficulties in implementation process takes time to be solved.

\section{The weakness of domestic enterprises}

"The Belt and Road" plan is viewed as an open economic development strategy. Its core idea is to develop the economy. In this way, the main body of the plan should be enterprises. The ideal goal is that government provides the platform, and enterprises actually carry on the plan. Through the attraction of foreign investment and the improvement of infrastructure, the government can promote local enterprises to go abroad.

This requires that domestic enterprises have leading economic perceptions and a consensus with international value so that they can improve comparative advantages. However, in fact, domestic enterprises lack deep understanding of rules of trade liberalization. The different interests lead to the negative trend; that is complex trade conflicts will occur more frequently. It represents that Chinese enterprises are not good at getting the opportunity, exploring resources, and expanding business opportunities.

\section{High operating costs}

The abilities of enterprises are limited. Similarly, a drama is not just determined by actors on the stage, more importantly, it is the groundwork and savings under the stage. How the government builds the platform for the enterprise, the construction of the infrastructure, the implementation of the system and regulations, the direction of any link will affect the ability of enterprises. The construction of infrastructure generally requires large investment, long cycle, but receives low rate of return. Therefore, the government should be responsible for it. If it is passed on to the enterprise, it definitely causes high operating costs of enterprises so that the non- profitable companies will complain incessantly in China.

\section{SOlutions OF "THE Belt AND RoAD”}

\section{A. Clear policies}

In terms of making the detailed plan of "The Belt and Road", it is better to learn the experience from developed countries, making full use of the international rules. "The Belt and Road" is to exchange some resources with other resources, take advantage of each other and complement with each other with different economic strategies. Zhao Jianglin (2015) [6] thinks that we should focus on the long-term objective and strategic exchange in the infinite space and time in order to obtain win-win situation in the long run.

The first suggestion is to reduce tariff and broaden fields for investment. Secondly, improve legal system make sure the system is open and fair. Next, is to adjust the strategy actively with a view to creating an opening environment.

The relationship between China and the world is interdependent. Instead of waiting for the world to open its arms to China, we should give priority to opening resources, the market and foreign investment. China should continuously adjust the strategy, satisfy its own requirements and needs of other countries and finally achieve a win-win situation.

\section{B. Formulate reasonable rules}

What is a reasonable rule? That is to comply with common rules. In the process of "The Belt and Road", China needs to make agreements with different countries, which is a continuous process of making rules. China must maintain the reasonable rules of international trade and actively be involved in the modification of existing rules or formulation of new rules of international trade. It is clear that every rule makers are the biggest beneficiaries finally. As a result, China should actively participate in the formulation of the rules, which objectively and accurately reflects the actual situation of international trade and strives for more interests for China.

\section{Optimize the strategic structure}

In the strategic structure, China should extend the current negotiations and improve the existing cooperative agreements. With bilateral treaties and regional cooperative platform, China should have joint negotiations with other countries on specific issues. On the basis of mutual benefits, we look after those countries along the Silk Road to improve those countries' own production capacity.

The construction of "The Silk Road Economic Zone" focuses on the establishment of the channel. To construct roads, railways and transportation infrastructure, and invest on transportation capacity across countries, China should accelerate the cooperation and negotiation with neighboring countries in these areas. In the facilitation of trade and investment, we should actively promote the border trade cooperation with Ukraine and Kazakhstan. In addition, in monetary and financial issues, it also provides some convenience, even the legal and policy support. 


\section{Vigorous economic diplomacy}

The implementation of "The Belt and Road" is a huge challenge to every area in China. In order to obtain more opportunities to speak, China will have more proactive attitude towards trade activities. China comes up with four keywords "pro, honesty, benefits, containment", which is the best interpretation of its economic diplomacy. In addition, pay attention to get rid of benefit- oriented of thinking pattern in the past. We need to reach an agreement on macro issues to seek for more long-term development. Moreover, Zeng Jing (2016) [7] insists that treat other countries affected by "The Belt and Road" openly and honestly regardless of the other country's economic strength. Other countries will be fully respected in the negotiations, and China will ensure that every cooperation can be supported by preferential policies, or even mutual interconnection. Finally, care about the interests of the partners, share common management consciousness. When either side encounters difficulties, both sides should cooperate to seek common points while reserving differences.

\section{E. Internal resources integration}

First of all, the economic diplomacy has become one of the most important diplomacy. It must be incorporated into the overall national development strategy. "The Belt and Road" is not only the economic and trade cooperation between countries, but also an attempt of national diplomatic strategy. It involves the overall economic security of the country, and must be integrated into the overall national economic security strategy. In specific implementation process, the State Council and the ministries and commissions, local governments and other executive departments come up with concrete implementation plans, overall arrangements, and solid implementation. Secondly, the roles of the chamber of Commerce or guild of Chinese enterprises cannot be ignored in international trade negotiations. The essence of "The Belt and Road" is the mutual reciprocity and mutual benefit, and works as a bridge between governments, the chamber of Commerce, guild and enterprises in different industries. It can balance the interests of different parties for the government to provide public relations, trade consultation, market research and related information and technical support at home and abroad in the negotiations. Therefore, more market space should be set aside for the chamber of Commerce and the guild to ensure its initiative and enthusiasm in space and time. In addition, it is to cultivate the sense of participation and awareness of construction in the enterprises in our country in dealing with trade disputes in the negotiations, when China goes abroad. They realize that they are not isolated in the face of unfair treatment, involving violation of relevant bilateral cooperation agreement and WTO rules. Enterprises should actively join together to seek help from the government, and the relevant official departments should play its leading role in protecting the legitimate rights and interests of enterprises. Departments should not only provide firms with support, but also enable enterprises to take the initiative to take their own responsibilities.

It is also important to correctly guide the media and take advantages of positive guiding role of the media. "The Belt and Road" is win-win cooperation, mutual advantageous game in the present. The speed of information dissemination and its increasing impact on the public are suggested that the public should connect with the media in order to reduce misunderstanding and misjudgment and false information. Avoiding the pressure of public opinion caused by false reports results in Chinese economic and trade negotiations in a passive situation.

Relevant research institutions and experts and scholars should also play their own professional expertise, in the formulation of policies and rules, risk and feasibility assessment, good brains. Policy makers may need to establish good interaction with experts in various fields, by setting the topic widely and seeking good policy, benefit by mutual discussion, in the actual economic and trade negotiation process, some experts and scholars have enabled appropriate experience negotiating involved.

\section{CONCLUSION}

"The Belt and Road" is a key part of national strategy and starts a new round of China's reform and opening- up, which will help China go abroad, like the two wings of Chinese economy, especially its role on the economic development in Asia. There have been a growing number of countries joining. Many developing countries support and help solve overcapacity, lack of demand and look for new impetus for economic growth in China.

"The Belt and Road" policy can be expressed by the fact that the challenges and opportunities coexist in the implementation process. How the government builds a platform, establish the infrastructure and introduce the laws and regulations will influence the implementation of the policy by companies.

\section{ACKNOWLEDGMENT}

I want to express my appreciation to people who gave a hand to me during the completion of the article. I would like to thank my supervisor, Professor Liu Siyan. Without his instructions and encouragement, I would not finish this article in current form.

Last, I also owe a gratitude to SATIIM Conference which gives us an opportunity to discuss and communicate on "The Belt and Road" policy since I have already learned much from it.

\section{REFERENCES}

[1] M. Guo, and Y.Q. Feng, "How to Implement"The Belt and Road"Policy," Journal of Changchun Institute of Education, 2015, pp. 209-220

[2] J.L. Gao, "The Interaction with Foreign Reserve and 'The Belt and Road'," China Foreign Affairs University, 2015, pp. 23-50

[3] M.C. He, Y.B. Zhang, Y.P. Zhang, and B. Tian, "Problems and Suggestions Faced by 'The Belt and Road'," Journal of Xinjiang Normal University, 2015, pp. 178-203

[4] L. Sun, "Report on the Development of Central Asian Countries," Social Sciences and Literature Press, 2012, pp. 10-23

[5] L. Sun, "The Effect of the Multilateral Trade on Regional Integration and Chinese Solutions," Anhui University, 2015, pp. 56-70

[6] J.L. Zhao, "How to carry on 'The Belt and Road'," China Economic Report, 2015, pp. 101-120 
[7] Zeng Jing, "Problems and Solutions of International Trade under 'The Belt and Road'," China Journal of Commerce, 2016, pp. 123-125 